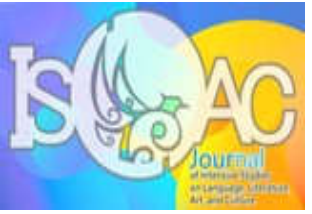

ISLLAC : Journal of Intensive Studies on Language, Literature, Art, and Culture

Volume 2 Issue. 1, 2018

Journal homepage : http://journal2.um.ac.id/index.php/jisllac

\title{
MULTIMODAL CONCEPTION IN LEARNING
}

\author{
Mochammad Bayu Firmansyah* \\ STKIP PGRI PASURUAN, Indonesia
}

A R T I C LE INF O

Keyword:

Halliday,

Views of Construtivism,

Multimodal

\begin{abstract}
A B S T R A C T
This article aims to formulate a multimodal conception in the learning hierarchy. This exposure is based on three things, namely: (1) Multimodal definitions vary, (2) Higher education curriculum, and (3) Findings of research on multimodal utilization in learning. The problem relates to the pedagogical aspects of multimodal learning in the view of constructivism. 21st century learning requires learners to be proficient in interpreting text, discourse to socio-culture. This issue then inspects the multimodal conception in order to formulate multimodal learning as an approach
\end{abstract}

\section{INTRODUCTION}

The multiplicity of multimodal definitions in learning, from one side, and the limited multimodal study of learning on the other hand, further encouraged the formulation of an appropriate multimodal theory to meet the learning needs. Multimodal theory is an opinion of multimodal based on research and invention supported by data and arguments. Several multimodal studies in the lessons below, further strengthen the expected multimodal theory.

First, the research shows that through multimodal text in English can develop students' communicative competence (Coccetta, 2018). The multimodal perspectives developed through the theory of language function systems (Halliday, 1977, 1978, Halliday \& Hasan, 1985) have been integrated into the English text learning syllabus for the purpose of developing students' communicative competence. In other words, students engage in learning text analysis by using worksheets to explore various semiotic sources that contribute to the meaning of the text. The ultimate purpose of integration in the syllabus is to introduce the overall communicative competence. Coccetta (2018) in his article ilustrates instruments for multimodal text analysis and examples of lego and youtube media used in learning.

Second, multimodal analysis of cartoons "Adit Sopo Jarwo episodes of Missing Meatballs" and "Upin and Ipin Episodes of Ecosystems" (Wulan, 2017). Multimodal analysis is discussed using verbal text analysis theory on Halliday language metaphunction (ideational function, interpersonal function, and textual function), while visual text using multimodal analysis (Kress, 1996, 2006; Cheong, 2004). Third, multimodal and literary materials can broaden cultural understanding, contextual understanding, dialect, and idiom (Kennedy, 2014). The use of literature and lyrics of multimodal songs (Let It Go, "Frozen"), to help English learners as a foreign language in improving vocabulary, grammar and precision, linguistic and confidence competence, motivation, cultural knowledge, empathy and objectivity literary awareness.

Fourth, multimodal discourse analysis focuses on how meaning is made through the use of multiple communication models (Cheng \& Liu, 2014). Film discourse is a typical multimodal discourse that contains many semiotic modes, such as images, text, sounds and music. Fifth, multimodal teaching approaches are used to teach poetry in ESL / EFL classes in Ecuador as well as to improve learners' attitudes toward learning English (Freyn \& Ed, 2017).

Sixth, multi-modal strategy approach (MMS) consisting of: (a) word, (b) member, (c) real thing, (d) diagram, (e) story, and (f) symbol can strengthen participants' educated in learning (Hamdi, Syukrul,

\footnotetext{
" Corresponding author.

E-mail addresses: firmansyahbayu970@gmail.com (Mochammad Bayu Firmansyah)
}

ISSN : 2597-7385 (Online) - ISLLAC : Journal of Intensive Studies on Language, Literature, Art, and Culture is licensed under Creative Commons Attribution-ShareAlike 4.0 International License (http://creativecommons.org/licenses/BY/4.0/).

40 | ISLLAC : Journal of Intensive Studies on Language, Literature, Art, and Culture 
2013). Seventh, multimodal theory in language learning increases the motivation and confidence of two Taiwan EFL learners (Lee, 2014). The focus of EFL Taiwanese learners to speak Mandarin is likely to be a visual learner. Thus, it is reasonable that multimodal need to be formulated into levels in learning that includes language learning theory, models, approaches, methods / strategies, techniques and procedures.

Through learning is expected to contribute positively to enhancing the capability of students in universities, both in the competition between nations and partnerships with other nations. In general, higher education aims: (a). Building Student to become a man of faith and cautious to God Almighty and have a noble, healthy, knowledgeable, capable, creative, independent, skilled, competent, and cultured for the benefit of the nation; (b). produce graduates who expert in science and/or technology to meet the national interest and increase the competitiveness of the nation; (c). the production of science and technology through research that concerns and implements the value of humanities to benefit the development of the nation, as well as the progress of human civilization and welfare; and D). the realization of community-based devotion to reasoning and research work which is useful in promoting the general welfare and the intellectual life of the nation (President of the Republic of Indonesia, 2012). Specifically, alluded to learning in the Higher Education Act number 12 of 2012 article 13 paragraph 1 and 2, namely: (1). students as members of the Academic Society are positioned as mature human beings who have their own awareness in developing their potential in universities to become intellectuals, (2). Students as referred to in paragraph (1) actively develop their potential by conducting learning, scientific truth seeking, and/or the mastery, development, and practice of a branch of Science and/or Technology to become scientists, intellectuals, practitioners, and/or professionals cultured.

The selection of university level as a research context in multimodal learning at least prepares students according to challenges, demands and learning needs of the 21st Century. Higher educational innovations are at least focused on: (a) building capabilities to achieve organizational and administrative excellence; (b) identification of potential exploitable knowledge assets for the growth of higher education innovation, and (3) the spatial development of the learning environment along with the design of experiential learning through research and development (Rofi'uddin, Saryono, Kamdi, \& Mukminatien, 2017). Starting from the above background, this article aims: (1) to formulate a multimodal conception in the learning hierarchy.

\section{MULTIMODAL IN CONSTRUCTIVISM VIEW}

Multimodal can be seen from language theory. In Halliday's view the language is seen as social semiotics. The forms of language encode (encode) a socially constructed the representation of world. The emphasis is on the social context of language, which is the social function that determines the form of language and how it develops (Halliday 1977, 1978, Halliday \& Hasan, 1985). Languages by Halliday are associated with human experience in terms of social structure; language is a product of social processes. In the social process the reality construct can not be separated from the semantic system constructs in which the reality is encoded. Thus, meaning will be dual. The formulation of language as social semiotics means to interpret the language in the sociocultural context in which it is interpreted in semiotic terms as an information system. In a very concrete level, the language contains no sentences, but contains text or discourse, ie exchange of meaning (exchange of meaning) in the interpersonal context. Assessing the language of its essence examines text or discourse. Based on this, Halliday's view can be one of the benchmarks to determine the development of multimodal theory.

Multimodal is an effort to understand various ways of representation of knowledge and making meaning (Jewitt and Kress, 2003). Multimodal focuses on the design of discourse by studying the contribution of semiotic sources (language, motion, image) deployed in various modalities (audio, visual, physical), as well as interaction and integration in text coherence process. The multimodal approach considers how linguistic and visual choices meet the purpose of texts, audiences and contexts, and how they work together in the organization and development of information and ideas (Lim \& Tan, 2017).

Constructivism is the philosophy of constructive knowledge (formation) of the subject itself (Piaget, 1971). The intended formation that the active subject creates cognitive structures in their interactions with the environment. With the aid of this cognitive structure, the subject makes sense of reality. Cognitive interaction will occur as far as reality. Cognitive interaction will occur as far as reality is structured through the cognitive structure created by the subject itself. The cognitive structure must always be altered and adapted according to the demands of the environment and the changing organism. The process of adaptation occurs continuously through the process of reconstruction. The focus of constructivist theory is learners in the learning process. Learn more directed at experiental learning that is an adaptation of humanity based on concrete experience, discussion with classmates who then contemplated and made idea and development of the new concept. Some of the things that concern 
constructivist learning are: (a) prioritizing real learning in the relevant context, (b) prioritizing processes, (c) inculcating learning in the context of social experience, and (d) learning is done in order to construct experience.

In line with the view of the contructivism, then multimodal in learning positioned as an approach to determine the competence of multimodal learners using a view of kontruktivisme. On the one hand, learners are sensitive to potential meanings and choices given in text production (O'Halloran \& Lim, 2011), while on the other hand constructivism is a cutting-edge learning model that puts learners activity in every educational interaction to be able to explore and found his own knowledge (Nurhasnawati, 2012).

\section{MULTIMODAL LITERACY DIMENSIONS IN LEARNING}

There are at least two dimensions of multimodal literacy that can reinforce the multimodal conception of the learning level. First, the dimension of multimodal literacy as a medium, which is related to the prevalence of multimodal text, especially multimedia texts given by digital media, emphasizes the need for literacy to generate and access information (Kress \& Leeuwen, 2001). Multimodal literacy recognizes the significancy of semiotic resources and modalities in the construct of meaning. The semiotic source is not reduced to a paralinguistic resource that is in addition to language, but is seen as a semiotic source given the same status as language and is equally effective in semiosis. The language functions and constraints of each of the semiotic sources as well as their contribution to the multimodal discourse are also considered. The difference in semiotic resources brings with it both the capabilities and constraints both individually and in combination and challenge analysis in terms of media properties, detail and scope of analysis and complexity arising from the integration of semiotic resources across cultures (Kress \& Leeuwen, 2001).

So that is said multimodal literation learners must be sensitive to the potential meaning and choice provided in text production in order to increase the ability to make deliberate and effective choices in construction and presentation of knowledge. The provision makes learners not only a consumer who understands multisemiotic texts but also makes learners the producers of competent multimodal texts. Secondly, the dimension of multimodal literacy as a multisemiotic experience involves the recognition that multisemiotic and multimodal learning experiences. Reading people in everyday life ranging from the form of facial expression, attitude, gestures, actions and clothing typical (O'Toole, 1994).

While new media technologies have put forward the multimodal nature of communication, meaning is always built and interpreted multimodally through the use of semiotic resources such as language and physical resources such as movement and posture in different sensory modalities through sight, smell, taste and touch. Movement, sound, and all material things carry interactional meanings after they are perceived by someone (Norris, 2004). In this sense, all interactions are multimodal. Communication is more than what is said and heard but by what we feel through expression, gaze, touch, and movement. Therefore, there is a need to understand how the learning process is built through the use of multimodal literacy from the utilization of semiotic resources as outlined in the lesson planning. Appreciating the functional capabilities and constraints of semiotic resources and modalities and how deployment in the learning process can provide understanding that can lead to more effective teaching and learning in the classroom (Lim, 2010; O'Halloran \& Podlasov, 2011).

From the multiple perspective of multimodal literacy in multimodal text and in multisemiotic experiences, multimodal literary input has two aspects: (a) cultivating multimodal discourse analysis skills for learners, and (b) sensitivity in the use of multimodal resources (capabilities and constraints, processes , contextual relationships) and the potential to form a learning experience in the classroom.

\section{MULTIMODAL LITERACY LEARNING}

The systemic approach to teaching visual texts emphasizes the explicit teaching of the common features of visual texts and introduces a common multimodal strategy used to engage learners. It aims to provide a pedagogical foundation that informs system theory of functions and understanding from multimodal research. Provide experience in the learning process of learners with the proper use of the structure and meta language to interpret visual texts.

The naming of a systemic approach remembers the root foundation in systemic functional multimodal discourse analysis (SFMDA) (Jewitt, Bezemer and O'Halloran 2016; O'Halloran and Lim, 2014), which is a functional system theory application developed by Halliday (1985). The term systemic also describes the organizations underlying the semiotic resources that make it possible to be used for a variety of purposes (Lim, 2010; O'Halloran \& Podlasov, 2011). Systems of meaning are usually modeled as interconnected "network systems" (Halliday and Matthiessen, 2004; Martin 1992; Kress and van Leeuwen, 2006) to illustrate the potential meaning of semiotic sources (O'Halloran and Lim, 2014). 
The pedagogy of the systems approach to multimodal text teaching involves learners who study the various system options available in language and images. This teaching is introduced using the system options available to text producers over the network system. Learners are taught to identify text choices, explain, and interpret meaning in the multimodal text. Learning can be done through several levels with text annotations and technological tools. Learners are encouraged to support their interpretation of multimodal texts by citing the textual evidence of their analysis. This is achieved through a worksheet designed with questions to direct students from textual descriptions to textual analysis.

Finally, learners are given the opportunity to articulate their perspectives and communicate their ideologies in multimodal text by identifying strategies used to attract readers. Learners can be invited to present their analysis and maintain their interpretation of the text to the class.

\section{CONCLUSIONS}

The multiplicity of multimodal definitions encourages to redefine these definitions into conceptions that are related in the learning hierarchy. Therefore, please note that the multimodal position in learning has its own characteristics in learning. Furthermore, to make multimodal as an approach in learning, conception must be done as an early stage before it is finally applied in college learning.

\section{REFERENCES}

Cheng, Y., \& Liu, W. (2014). A Multimodal Discourse Analysis of the Relationship between Pi and Richard the Tiger in the Movie Life of Pi. International Journal of Language and Literature, 2(4), 191-219. https://doi.org/10.15640/ijll.v2n4a11

Coccetta, F. (2018). Developing university students' multimodal communicative competence: Field research into multimodal text studies in English. System, 1-9. https://doi.org/10.1016/j.system.2018.01.004

Freyn, A. L., \& Ed, D. (2017). Effects of a Multimodal Approach on ESL / EFL University Students ' Attitudes towards Poetry, $8(8), 80-83$. Retrieved from ISSN 2222-1735 (Paper) ISSN 2222-288X (Online)

Halliday, M.A.K. (1977). Language as Social Semiotic: Towards as General Sociolinguistic Theory. Dalam Makkai, A., Makkai, V.B., \& Heilmann, L. (Eds.), Linguistics at the Crossroads (hlm. 13-41). Padova: Tipografia-La Garangola.

Halliday, M.A.K. (1978). Language as Social Semiotic: The Social Interpretation of Language and Meaning. London: Edward Arnold.

Halliday, M.A.K. (1985/1994). An Introduction to Functional Grammar. London: Edward Arnold Publishers Ltd.

Halliday, M.A.K. \& Hasan, R. (1992). Bahasa, Konteks, dan Teks: Aspek-Aspek Bahasa dalam Pandangan Semiotik Sosial. Terjemahan oleh Barori Tou. Yogyakarta: Gajah Mada University Press.

Hasan, R. \& Martin, J.R. Introduction. Dalam Hasan, R. \& Martin, J.R. (Eds.), (1989). Language Development: Learning Language, Learning Culture (Meaning and Choice in Language: Studies for Michael Halliday)(hlm. 1 17). Norwood-New Jersey: Ablex Publishing Corporation.

Halliday, M. A., \& Christian, M. I. M. (2004). Matthiessen. An introduction to functional grammar.

Hamdi, Syukrul, A. (2013). DALAM PEMBELAJARAN MATEMATIKA MELALUI PENDEKATAN MULTI-MODAL STRATEGY ( MMS ). In Prosiding (pp. 978-979).

Jewitt, C., \& Kress, G. R. (Eds.). (2003). Multimodal literacy. New York: Lang.

Jewitt, C., Bezemer, J., \& O'Halloran, K. (2016). Introducing multimodality. Routledge

Kennedy, V. (2014). Critical, cultural and multimodal approaches to using song as literature in language learning. Libri \& Liberi, 3(2), 295-310.

Kress, G., \& Van Leeuwen, T. V. (2001). Multimodal discourse: The modes and media of contemporary communication.

Kress, G., \& Van Leeuwen, T. (1996). 2006. Reading images: The grammar of visual design.

Lee, H. (2014). Using an arts-integrated multimodal approach to promote English learning: A case study of two Taiwanese junior college students HSIAO-CHIEN LEE. English Teaching: Practice and Critique, 13(2), 55-75.

43 | ISLLAC : Journal of Intensive Studies on Language, Literature, Art, and Culture 
Martin, G., Montagne-Clavel, J., \& Oliveras, J. L. (1992). Involvement of ventromedial medulla" multimodal, multireceptive" neurons in opiate spinal descending control system: a single-unit study of the effect of morphine in the awake, freely moving rat. Journal of Neuroscience, 12(4), 1511-1522.

O'Halloran, K. L., Tan, S., Smith, B. A., \& Podlasov, A. (2011). Multimodal analysis within an interactive software environment: critical discourse perspectives. Critical Discourse Studies, 8(2), 109-125.

O’Halloran, K. L., \& Lim-Fei, V. (2011). Dimensioner af multimodal literacy. Viden om Læsning, 10, 14-21.

O'Halloran, K., Podlasov, A., Chua, A., Tisse, C., Lim, F., \& Smith, B. (2014). Challenges and solutions for multimodal analysis: Technology, theory and practice. In Developing systemic functional linguistics: Theory and application (pp. 271-297). Equinox.

O'Halloran, K.L. \& Lim, F. V. (2011), 'Dimensioner af Multimodal Literacy', Viden om Læsning 10, September 2011: 14-21, Copenhagen, Denmark: Nationalt Videncenter for Laesning.

O'toole, M. (1994). The language of displayed art. Fairleigh Dickinson Univ Press.

Norris, P. (2004). Electoral engineering: Voting rules and political behavior. Cambridge university press.

Nurhasnawati. (2012). Model-model pembelajaran. PT Rajagrafindo Persada, 237-259.

Piaget, J. (1971). Psychology and epistemology (A. Rosin, trans.). New York: Grossman.

Wulan, A. P. (2017). Analisis Wacana Dan Edukasi : Semiotik Multimodal Kartun Indonesia " Adit Sopo Jarwo Episode Bakso Hilang ” Vs Kartun Malaysia “ Upin - Ipin Episode Ekosistem ,” (February), 11041117.

44 | ISLLAC : Journal of Intensive Studies on Language, Literature, Art, and Culture 